\title{
Effect of Fasting and Streptozotocin Diabetes on Insulin Binding and Action in the Isolated Mouse Soleus Muscle
}

\author{
Y. Le MarChand-Brustel and P. Freychet, Institut National de la Santé et de la \\ Recherche Médicale, Groupe de Recherches sur les Hormones Polypeptidiques \\ et la Physiopathologie Endocrinienne, U 145, and Laboratoire de Médecine \\ Expérimentale, Faculté de Médecine, Université de Nice, Chemin de \\ Vallombrose, 06034 Nice Cedex, France
}

A B S T R A C T To investigate whether skeletal muscle is resistant to insulin in insulinopenic states, insulin binding and biological effects on glucose utilization were studied in isolated soleus muscles from 24 - or 48-h-fasted mice and from streptozotocin-diabetic mice. Both 48-h fasting and diabetes led to an increase in insulin binding at insulin concentrations $<3.4 \mathrm{nM}$. In both states, submaximal concentrations of insulin were also more effective in stimulating muscle 2-deoxyglucose uptake and glycogen synthesis, and in activating glycogen synthase. This resulted in a two- to fourfold leftward shift in the insulin dose-response curves in muscles from both groups compared with control. No change in insulin binding or biological effects was detected in muscles from 24-h-fasted mice. Maximal insulin effectiveness on 2-deoxyglucose uptake and glycolysis was either unchanged or only slightly enhanced in 48-h-fasted mice and in diabetic animals, compared with controls. Maximal insulin effects on glycogen synthesis and glycogen synthase activation were unaltered by fasting or diabetes. Basal glucose uptake and glycolysis were similar in all groups of mice. In conclusion, when soleus muscles from 48 -hfasted mice and from diabetic mice are compared with controls it can be observed that, $(a)$ at low insulin concentrations insulin binding is increased and insulin effectiveness in stimulating glucose transport and metabolism is enhanced; (b) biological response's to maximally effective insulin concentrations are either unaltered or slightly increased; $(c)$ basal rates of glucose transport and metabolism are essentially unaltered. These results indicate that in insulinopenic states soleus muscle is not insulin resistant in vitro but is hyper-

Portions of this study appeared in abstract form in 1978. Diabetologia. 15: 249.

Received for publication 5 March 1979 and in revised form 21 June 1979. sensitive to low concentrations of insulin, and normally responsive to maximally effective doses of the hormone.

\section{INTRODUCTION}

Fasting and insulinopenic diabetes are characterized by insulinopenia and altered glucose metabolism. In adipocytes, it has been demonstrated that fasting and streptozotocin diabetes are accompanied by an increase in insulin binding associated with a profound decrease of basal and insulin-stimulated glucose metabolism (1-6). In muscle, insulinopenic diabetes and starvation have been reported to lead to a decreased glucose transport and responsiveness to insulin (7-9). The latter studies, however, involved the heart and the diaphragm which are highly specialized, constantly contracting muscles, not representative of the skeletal muscle mass. Other studies, performed in the perfused hindquarter from starved or ketoacidotic diabetic rats (1012), have indeed suggested that important differences exist between heart and skeletal muscle in the regulation of glucose metabolism.

In contrast to the many reports dealing with adipocytes (1-6), there is to our knowledge no available study concerning insulin binding and action in skeletal muscle in insulinopenic states. Yet, skeletal muscle is a major site of insulin action and glucose utilization. We have recently shown that it is possible to measure both insulin binding and biological effects in the isolated mouse soleus $(13,14)$, a slow-twitch red skeletal muscle. The present experiments have been undertaken to investigate whether the intrinsic function of the soleus with regard to insulin binding and action on glucose metabolism is altered in insulinopenic states such as fasting and streptozotocin diabetes in mice.

\section{METHODS}

Animals. 7- to 8-wk-old Swiss albino mice were used throughout this study. Unless otherwise indicated, they were 
fed ad lib. with UAR laboratory chow (Villemoisson, Epinay/ Orge, France), containing $21 \%$ protein, $4 \%$ fat, and $51 \%$ carbohydrate until the time of sacrifice (9-11 a.m.). Mice were maintained in a constant temperature $\left(23^{\circ} \mathrm{C}\right)$ animal room, with a fixed 12-h artificial light cycle. In fasting experiments, mice were deprived of food but had free access to water. Diabetes was induced by an intraperitoneal injection of streptozotocin ( $200 \mathrm{mg} / \mathrm{kg}$ body wt) following a 6-h fast; animals were then allowed free access to food and water, and were studied $10 \mathrm{~d}$ after injection. Mice were checked for hyperglycemia $72 \mathrm{~h}$ before sacrifice: under light ether anesthesia a blood sample $(50 \mu \mathrm{l})$ was withdrawn from the retroorbital sinus, centrifuged at $4^{\circ} \mathrm{C}$, and the plasma used for glucose determination (15).

Soleus muscle isolation. Mice were killed by cervical dislocation and soleus muscles were isolated as previously described (16). Muscles were removed from the leg, attached to a stainless steel holder, and suspended individually in flat-bottomed glass tubes. Each muscle was immersed in $1.5 \mathrm{ml}$ of Krebs-Ringer bicarbonate buffer ( $\mathrm{pH} 7.35$ ) containing 20 $\mathrm{mg} / \mathrm{ml}$ defatted bovine albumin (KRB-BSA) ${ }^{1}$ (17) and the additions specified for each experiment. The tubes were sealed with rubber stoppers and gassed with $\mathrm{O}_{2}: \mathrm{CO}_{2}$ (95:5, vol:vol) during the preincubation period and the first $10 \mathrm{~min}$ of the incubation. Muscles were always preincubated for an initial 15-min period and then incubated using the following procedure.

Insulin binding studies. Muscles were incubated for $4 \mathrm{~h}$ at $20^{\circ} \mathrm{C}$ in $1.5 \mathrm{ml}$ of the KRB-BSA buffer, supplemented with $2 \mathrm{mM}$ pyruvate and containing ${ }^{125} \mathrm{I}$-insulin (specific activity $200-240 \mu \mathrm{Ci} / \mu \mathrm{g}$, i.e., $1,200-1,400 \mathrm{Ci} / \mathrm{mmol}$ ) at $0.8-1 \mathrm{ng} / \mathrm{ml}$ (i.e., $0.13-0.17 \mathrm{nM}$ ) and varying concentrations of unlabeled insulin (13). Some muscles were incubated with unlabeled insulin at $50 \mu \mathrm{g} / \mathrm{ml}$ (i.e., $\cong 8,000 \mathrm{nM}$ ) to measure nonspecific binding (13). After $4 \mathrm{~h}$, when a steady state of insulin binding (13) was achieved, muscles were washed six times with $3 \mathrm{ml}$ of chilled isotonic $\mathrm{NaCl}$ containing $2.5 \mathrm{mg} / \mathrm{ml}$ of human serum albumin, each washing step consisting of a 5-min incubation period. ${ }^{2}$ After washing, muscles were dissolved in $0.3 \mathrm{ml}$ of $1 \mathrm{~N} \mathrm{NaOH}$ and counted for ${ }^{125} \mathrm{I}$ radioactivity.

Deoxyglucose uptake studies. Deoxyglucose uptake was measured at $20^{\circ}$ or $37^{\circ} \mathrm{C}$. At $20^{\circ} \mathrm{C}$, 2-deoxy-D-[1-14 C]glucose $(0.5 \mathrm{mM}, 1 \mu \mathrm{Ci} / 1.5 \mathrm{ml})$ was added to the incubation medium at the end of the 4-h incubation period described above, and the incubation was continued for $15 \mathrm{~min}$. When uptake was measured at $37^{\circ} \mathrm{C}, 2$-deoxy-D-[ $\left[1{ }^{14} \mathrm{C}\right]$ glucose $(0.1-10 \mathrm{mM}, 0.2$ $\mu \mathrm{Ci} / 1.5 \mathrm{ml}$ ) was added for $10 \mathrm{~min}$ at the end of a $30-\mathrm{min}$ incubation period with or without insulin. Initial rates of uptake were measured under these conditions of temperature and incubation duration (not shown). After washing as described above, muscles were dissolved in $0.3 \mathrm{ml}$ of $1 \mathrm{~N} \mathrm{NaOH}$ and counted for ${ }^{14} \mathrm{C}$ radioactivity.

Glucose metabolism studies. Glucose utilization by muscle was studied by measuring simultaneously, from $D-\left[5-{ }^{3} \mathrm{H}\right] \mathrm{glu}$ cose, the rate of formation of ${ }^{3} \mathrm{H}_{2} \mathrm{O}$, an index of glycolysis (18), and the incorporation of ${ }^{3} \mathrm{H}$ into glycogen at $37^{\circ} \mathrm{C}$. Muscles were preincubated twice for $15 \mathrm{~min}$ in the KRB-BSA buffer supplemented with $2 \mathrm{mM}$ pyruvate. Insulin at varying concentrations was present during the second preincubation and the subsequent 60 -min incubation; the latter was performed

\footnotetext{
${ }^{1}$ Abbreviation used in this paper: KRB-BSA, Krebs-Ringer bicarbonate buffer with $20 \mathrm{mg} / \mathrm{ml}$ defatted bovine albumin.

${ }^{2}$ This washing procedure at $0^{\circ} \mathrm{C}$ decreased nonspecific binding without decreasing specific binding (data not shown). It should also be noted that dissociation of ${ }^{125} \mathrm{I}$-insulin from soleus muscles represents only $15 \%$ of steady-state binding when measured over $30 \mathrm{~min}$ at $20^{\circ} \mathrm{C}(14)$.
}

in the presence of $\mathrm{D}-\left[5-{ }^{3} \mathrm{H}\right]$ glucose $(5 \mathrm{mM}, 1 \mu \mathrm{Ci} / 1.5 \mathrm{ml})$. At the end of the incubation, ${ }^{3} \mathrm{H}_{2} \mathrm{O}$ in the medium and labeled glycogen in muscles were measured as described previously (16).

Glycogen synthase activation studies. For measurement of glycogen synthase activity, muscles were preincubated for $90 \mathrm{~min}$ at $37^{\circ} \mathrm{C}$ in the KRB-BSA buffer supplemented with $2 \mathrm{mM}$ pyruvate, and incubated for $30 \mathrm{~min}$ in the same medium containing varying concentrations of insulin. At the end of the incubation, muscles were freeze-clamped in liquid nitrogen, powdered with a pestle precooled in liquid nitrogen, and briefly sonicated (Alcatel Sonifier, Paris, France) at $0^{\circ} \mathrm{C}$ in 0.5 $\mathrm{ml}$ of cold buffer (50 mM Tris-buffer, pH 8.2, 5 mM EDTA, 100 $\mathrm{mM}$ potassium fluoride) to achieve homogenization. After centrifugation of homogenates at $10,000 \mathrm{~g}$ for $5 \mathrm{~min}$ at $4^{\circ} \mathrm{C}$, supernates were collected and assayed immediately.

Glycogen synthase activity was assayed essentially as described by Thomas et al. (19). Samples (30 $\mu$ l) were added to $60 \mu \mathrm{l}$ of a solution containing $50 \mathrm{mM}$ Tris-buffer (pH 7.8), $15 \mathrm{mM} \mathrm{Na}_{2} \mathrm{SO}_{4}, 20 \mathrm{mM}$ EDTA, $25 \mathrm{mM}$ potassium fluoride, 9 $\mathrm{mg} / \mathrm{ml}$ glycogen, and $6.7 \mathrm{mM}$ UDP-[U-14 C]glucose $(20 \mathrm{nCi})$, and were thereafter incubated for $15 \mathrm{~min}$ at $30^{\circ} \mathrm{C}$. Glycogen synthase active (I) form is expressed as a percentage of the total $(I+D)$ synthase activity (defined as that measured under identical conditions except in the presence of $7.2 \mathrm{mM}$ glucose6-phosphate). Total glycogen synthase activity is expressed as nanomoles of UDP-glucose incorporated into glycogen per minute and per milligram of muscle protein. Because of interanimal variations in the basal percentage of glycogen synthase I activity (measured in muscles incubated without insulin), the two soleus muscles from one mouse were used as a pair (incubated with or without the hormone) in some experiments. In this case the $t$ test for paired data was used to determine the statistical significance of the results. Glycogen content was measured in muscles as described elsewhere (20).

Plasma determinations. Mice were anesthetized with sodium pentobarbital ( $100 \mathrm{mg} / \mathrm{kg}$ body wt i.p.) and a blood sample was withdrawn from the inferior vena cava, using a heparinized syringe. Blood samples were centrifuged at $4^{\circ} \mathrm{C}$ and the plasma was used for determination of glucose by the glucose oxidase method (15) and immunoreactive insulin (21) with mouse insulin used as standard.

Calculations and statistics. An aliquot sample of alkaline muscle solution was kept for protein determination of each individual muscle preparation, human serum albumin being used as standard (22). All results are expressed per milligram of protein and are presented as the means \pm SEM for the number of individual muscles indicated in the figure legends. Statistical significance was assessed by $t$ test for unpaired comparisons (23), unless otherwise indicated.

Materials. Streptozotocin was a gift from the Upjohn Co. (Kalamazoo, Mich.). Porcine monocomponent insulin and mouse insulin were gifts from J. Schlichtkrull (Novo Research Institute, Copenhagen, Denmark) and G. Jouve (Novo Laboratories, Paris, France). ${ }^{125}$ I-Insulin was prepared as previously described (13). Radioactive substances were purchased from the Radiochemical Centre (Amersham, England) or from New England Nuclear (Dreieichenhain, West Germany). Glycogen, UDP-glucose and glucose-6-phosphate were from C. F. Boehringer and Sons (Mannheim, West Germany). Other chemicals (analytic grade) were purchased from Merck A. G. (Darmstadt, West Germany) or from Sigma Chemical Co. (St. Louis, Mo.).

\section{RESULTS}

Experimental animals. Some characteristics of the experimental animals are presented in Table I. Body 
TABLE I

Characteristics of Experimental Animals

\begin{tabular}{lcccc}
\hline & Control & 24-h-fasted & 48-h-fasted & Diabetic \\
\hline Weight, $g$ & & & & \\
Before & & $29.3 \pm 0.5$ & $32.2 \pm 0.4$ & $\begin{array}{c}31.1 \pm 0.4 \\
\text { After }\end{array}$ \\
& & $(6)$ & $(20)$ & $(12)$ \\
Plasma & $(18)$ & $(6)$ & $(20)$ & $\begin{array}{c}26.2 \pm 0.5 \\
(12)\end{array}$ \\
Insulin, $n g / m l$ & & & & \\
& $2.12 \pm 0.21$ & $0.28 \pm 0.02$ & $0.55 \pm 0.06$ & $0.23 \pm 0.01$ \\
Glucose, $m g / 100$ ml & $(18)$ & $(6)$ & $(20)$ & $(19)$ \\
& $185 \pm 5$ & $124 \pm 13$ & $148 \pm 9$ & $613 \pm 15$ \\
Soleus muscle & $(18)$ & $(6)$ & $(7)$ & $(19)$ \\
Wet weight, $m g$ & & & & \\
& $8.8 \pm 0.3$ & $7.1 \pm 0.1$ & $7.8 \pm 0.1$ & $6.6 \pm 0.2$ \\
Protein, $m g / m u s c l e$ & $(24)$ & $(12)$ & $(28)$ & $(26)$ \\
& $1.69 \pm 0.05$ & $1.36 \pm 0.02$ & $1.65 \pm 0.03$ & $1.40 \pm 0.03$ \\
Glycogen, $\mu g / m g$ protein & $(24)$ & $(12)$ & $(28)$ & $(12)$ \\
& $30.6 \pm 1.4$ & $5.4 \pm 0.3$ & $5.8 \pm 0.4$ & $12.8 \pm 1.3$ \\
& $(12)$ & $(12)$ & $(14)$ & $(14)$ \\
\hline
\end{tabular}

Plasma glucose and insulin were determined before muscle isolation. Muscle wet weight, protein, and glycogen contents were measured after removal of tendons, without any prior incubation. Values are means \pm SEM, the number of values are given in parentheses.

weight markedly decreased during fasting or after streptozotocin injection. At the dosage used $(200 \mathrm{mg} / \mathrm{kg}$ body wt), streptozotocin induced a severe diabetes without ketoacidosis in mice. Both fasted and streptozotocin-diabetic mice were hypoinsulinemic, but glycemia changed in opposite directions: fasted mice were hypoglycemic whereas streptozotocin-diabetic mice were markedly hyperglycemic. After a 48-h fast, muscle weight decreased by $10 \%$ but protein content was unchanged; in diabetic mice, muscle weight and protein content were decreased by $20 \%$. Muscle glycogen content decreased markedly during fasting and streptozotocin diabetes.

Insulin binding to soleus muscles of fed, fasted, and streptozotocin-diabetic mice. As previously described (13), when ${ }^{125}$ I-insulin was incubated with individual soleus muscles a specific binding of the hormone was observed, that was inhibited by unlabeled insulin (Fig. 1). The binding of ${ }^{125}$ I-insulin and its inhibition by unlabeled insulin were similar in control and in 24-hfasted mice (Fig. 1A). In contrast 48-h fasting (Fig. 1B) and diabetes (Fig. 1C) resulted in an increase in the ability of soleus muscles to bind insulin at hormone concentrations $<3.4 \mathrm{nM}^{3}$ As total insulin concentra-

\footnotetext{
${ }^{3}$ Although there was some variability in insulin binding between series of experiments (as shown in Fig. 1B and C for
}

tion increased, the percentage of ${ }^{125}$ I-insulin bound decreased to a greater extent in 48-h-fasted mice and diabetic mice than in controls (Fig. 1). Table II shows that at low insulin concentrations (0.17-1.15 nM) muscles from 48-h-fasted and from diabetic mice bound significantly more insulin than did muscles from controls; at higher insulin concentrations, the amount bound was comparable for all groups. Taken together, these data suggest that muscles from 48-h-fasted and diabetic mice have a higher overall affinity for insulin than muscles from controls, but have the same total number of receptors. This conclusion is supported by Scatchard (24) plots of the binding data (Fig. 2), which show that the first part of the curves (at low level of binding) is steeper for 48-h-fasted and diabetic mice than for controls. However, it should be pointed out that this binding assay, which requires five to six individual muscles for each determination, is not suited for a large number of concentration points and therefore does not permit a detailed quantitative analysis.

control animals), differences in binding between controls and insulinopenic animals were consistently and reproducibly observed within each experiment. Interassay variations, although not specifically studied, could reflect the use of different preparations of ${ }^{125}$ I-insulin and/or seasonal variations pertaining to the mice. 


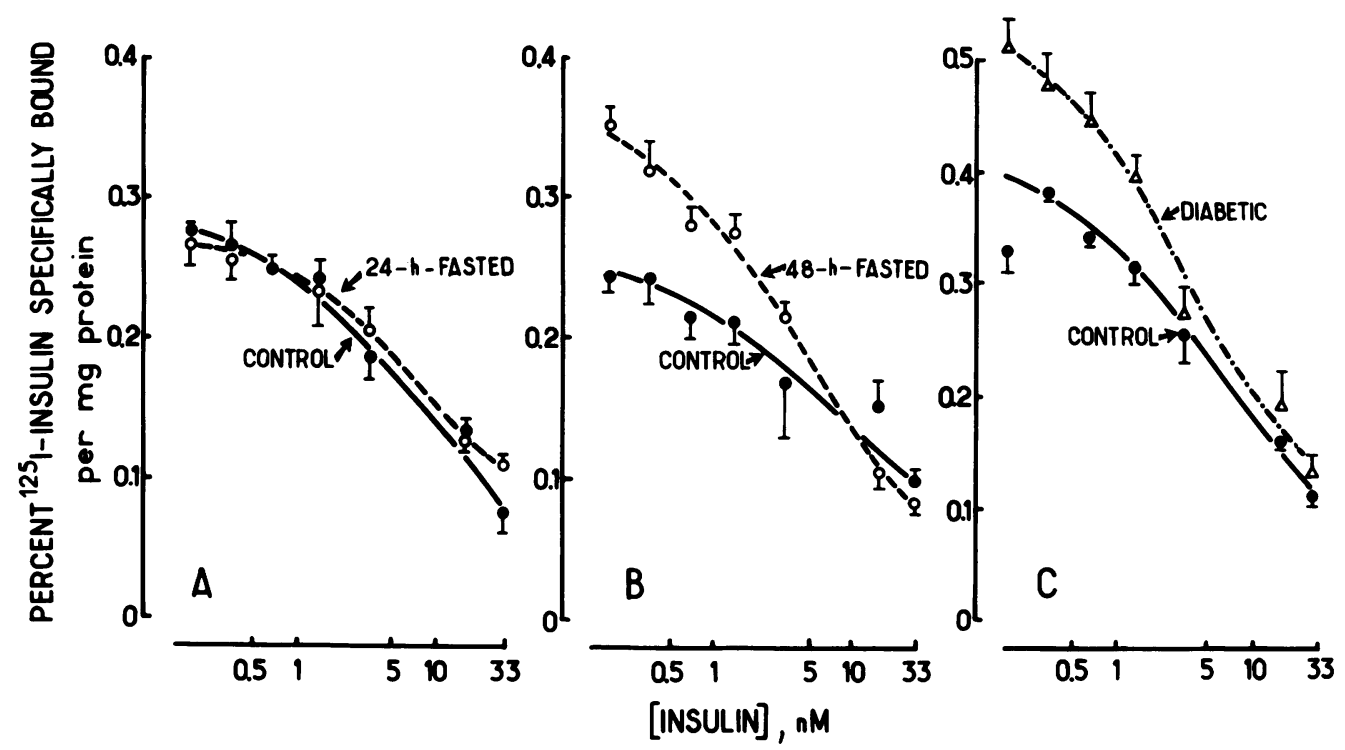

FIGURE 1 Insulin binding to soleus muscles of control, fasted, and streptozotocin-diabetic mice. Muscles were incubated for $4 \mathrm{~h}$ at $20^{\circ} \mathrm{C}$ in $1.5 \mathrm{ml} \mathrm{KRB-BSA,} 2 \mathrm{mM}$ pyruvate, ${ }^{125} \mathrm{I}$-insulin at $0.8 \mathrm{ng} / \mathrm{ml}$ $(0.14 \mathrm{nM})$, and unlabeled insulin to give the total insulin concentrations indicated on the abscissa. The amount of insulin nonspecifically bound (measured in the presence of unlabeled insulin at $8 \mu \mathrm{M}$ ) did not differ among the different groups of mice, and has been subtracted from each value. At the end of incubation, the washing procedure and protein determination were performed for each individual muscle as described in Methods. Each point is the mean \pm SEM of 6-12 muscles from two to four separate experiments; within each experiment, determinations were performed for each concentration point using three individual muscles from control or experimental mice. Differences were not significant between control and 24-h-fasted mice (A); differences were significant between control and 48-h-fasted mice (B), or between control and streptozotocindiabetic mice $(\mathrm{C})$ with $P$ between $<0.02$ and $<0.05$ at insulin concentrations $<3.4 \mathrm{nM}$.

Insulin effect on 2-deoxyglucose uptake in muscles of control, fasted, and streptozotocin-diabetic mice. The uptake of 2-deoxyglucose by muscles was used as an index of glucose transport and phosphorylation. As shown in Fig. 3A, muscles from 48-h-fasted mice accumulated significantly more 2-deoxyglucose at all insulin levels than did muscles from controls; the basal value of 2-deoxyglucose uptake (in the absence of insulin) was similar in control and 48-h-fasted mice. After a 24-h-fast, 2-deoxyglucose uptake was not significantly different from that observed in controls, in the absence as well as in the presence of submaximal and maximal concentrations of insulin (not shown). In diabetic mice the uptake of 2-deoxyglucose was also increased compared with controls (Fig. 3B) but only at submaximal concentrations of the hormone. When the results were expressed as percent of maximal insulin effect (Fig. 3C), the dose-response curves in muscles from 48-h-fasted and from streptozotocin-diabetic mice were shifted to the left by a factor of $2-3$, compared with that obtained in muscles from control mice. This is in agreement with the observation that at submaximally stimulating concentrations of insulin (i.e., $<3 \mathrm{nM}$ ), higher amounts of binding were achieved with the same concentrations of hormone in 48-h-fasted and in diabetic mice than in controls (Table II).

Basal and maximally insulin-stimulated 2-deoxyglucose uptake was measured at increasing concentrations of 2-deoxyglucose in muscles of control and 48-h-fasted mice. Uptake was similar in both groups of mice over the range of sugar concentrations tested (Fig. 4). The shape of the curves suggests two components: a saturable component observed at 2-deoxyglucose concentration $<2-5 \mathrm{mM}$, and a nonsaturable linear component at higher concentrations. Neither component was altered by fasting (Fig. 4). Table III also shows that phloridzin, an inhibitor of carrier-mediated glucose transport (25), prevented basal and insulin-stimulated sugar uptake to a similar extent in muscles from control and 48-hfasted mice.

Insulin effect on glycolysis in muscles of control, fasted, and streptozotocin-diabetic mice. To investigate the effect of insulin on more distal steps of glucose metabolism, glycolysis and glycogen synthesis were measured in muscles from control, fasted, or streptozotocin-diabetic mice. As shown in Fig. 5A, the insulin effect on glycolysis was only slightly increased in muscles from 24-h-fasted mice (the level of statistical 
TABLE II

Insulin Binding to Soleus Muscles of Control, 48-h-fasted and Streptozotocin-Diabetic Mice

\begin{tabular}{lcccc}
\hline & \multicolumn{4}{c}{ Insulin specifically bound } \\
\cline { 2 - 5 } Insulin & Control & 48 -h-fasted & Control & Diabetic \\
\hline$n M$ & \multicolumn{4}{c}{ fmol/mg protein } \\
0.17 & $0.61 \pm 0.03$ & $0.88 \pm 0.03^{*}$ & $0.82 \pm 0.05$ & $1.28 \pm 0.06^{*}$ \\
& $(11)$ & $(10)$ & $(6)$ & $(8)$ \\
0.34 & $1.23 \pm 0.08$ & $1.58 \pm 0.10 \rrbracket$ & $1.92 \pm 0.06$ & $2.39 \pm 0.16 \ddagger$ \\
& $(11)$ & $(10)$ & $(5)$ & $(5)$ \\
0.67 & $2.16 \pm 0.16$ & $2.81 \pm 0.13 \S$ & $3.47 \pm 0.10$ & $4.48 \pm 0.25 \S$ \\
& $(11)$ & $(10)$ & $(4)$ & $(4)$ \\
1.15 & $4.8 \pm 0.3$ & $6.2 \pm 0.3 \S$ & $7.2 \pm 0.4$ & $8.9 \pm 0.4 \ddagger$ \\
& $(11)$ & $(10)$ & $(5)$ & $(5)$ \\
3.40 & $8.4 \pm 2.1$ & $10.7 \pm 0.6$ & $13.2 \pm 1.4$ & $13.8 \pm 1.1$ \\
& $(11)$ & $(11)$ & $(3)$ & $(5)$ \\
17 & $39.0 \pm 4.5$ & $26.3 \pm 2.5 \ddagger$ & $41.7 \pm 2.0$ & $48.5 \pm 7.0$ \\
& $(9)$ & $(10)$ & $(5)$ & $(5)$ \\
33 & $49.1 \pm 4.0$ & $43.2 \pm 3.5$ & $55.0 \pm 4.5$ & $66.5 \pm 5.0$ \\
& $(10)$ & $(10)$ & $(5)$ & $(4)$ \\
\hline
\end{tabular}

Muscles were incubated as described in Fig. 1. The amount of insulin nonspecifically bound, which did not differ between control and fasted or diabetic mice, has been subtracted from each value. Values are means \pm SEM, with the number of muscles in parentheses. Differences between muscles from control and fasted or diabetic mice are significant where indicated with: ${ }^{*} P<0.001 ; \$ P<0.02 ; \$ P<0.01$.

significance being reached only at 0.34 and $6.7 \mathrm{nM}$ insulin). After a 48-h fast (Fig. 5B), glycolysis was significantly increased at all insulin concentrations (submaximal and maximal). No difference was observed for insulin-stimulated glycolysis between muscles from controls and streptozotocin-diabetic mice (Fig. 5C). The basal rates of glycolysis were similar in all groups of mice.

Insulin effect on glycogen synthesis and glycogen synthase activation in muscles of control, fasted, and streptozotocin-diabetic mice. The effect of insulin on glycogen synthesis from $\left[5-{ }^{3} \mathrm{H}\right]$ glucose is shown in Fig. 6. Insulin stimulated glycogen synthesis to a similar extent in muscles from controls and 24-h-fasted mice (Fig. 6A). Submaximal concentrations of insulin were more effective in muscles from 48-h-fasted and diabetic mice than in muscles from controls (Fig. 6B and C); with higher insulin concentrations, glycogen synthesis was not significantly different in muscles from 48-hfasted or diabetic mice compared with controls. The greater sensitivity of muscles from 48-h-fasted or diabetic mice to submaximally stimulating concentrations of insulin was more apparent when the results were expressed as a percentage of maximal insulin effect (Fig. 7): thus, half-maximal insulin effect was observed at $0.90 \pm 0.07 \mathrm{nM}$ (six experiments) for controls; $0.46 \pm 0.07 \mathrm{nM}$ (four experiments) for 48-h-fasted mice; 0.40 and $0.62 \mathrm{nM}$ (two experiments) for streptozotocin-diabetic mice. Basal glycogen synthesis (measured in the absence of insulin) was significantly lower in muscles from diabetic mice compared with controls (Fig. 6C).

The stimulation of glycogen synthesis by insulin could result from an increase in glucose transport and/or from an activation of glycogen synthase. It has been suggested (26) that activation of glycogen synthase by insulin in skeletal muscle occurs via a mechanism independent of the hormone's effect on glucose trans-

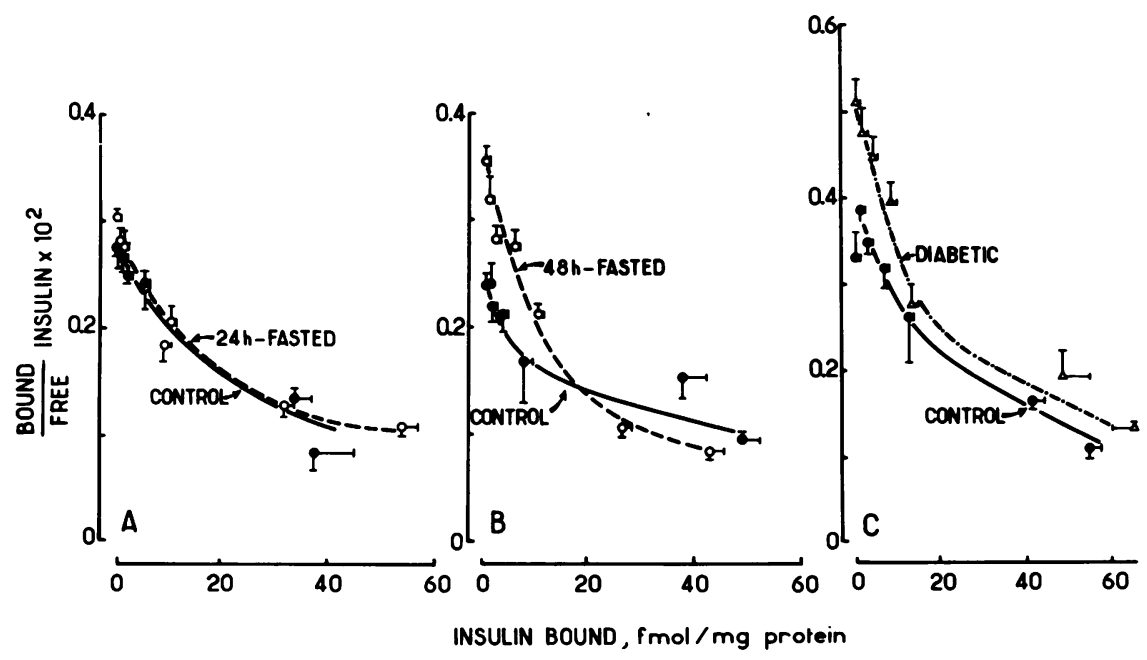

FIGURE 2 Scatchard plots of insulin binding to soleus muscles of control, fasted, and diabetic mice. Plots were derived from data shown in Fig. 1. 

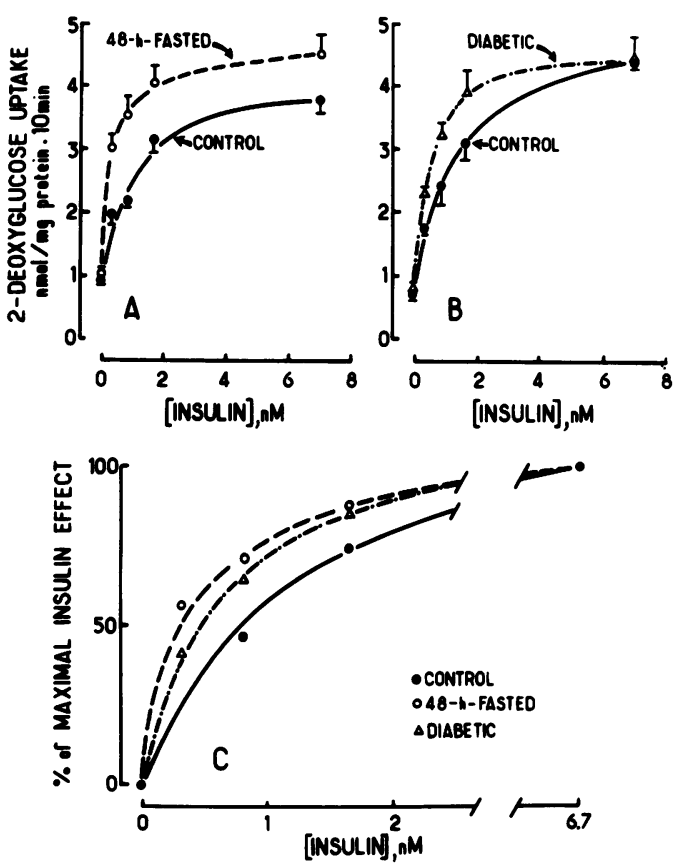

Figure 3 Insulin effect on deoxyglucose uptake in soleus muscles of control, fasted, and streptozotocin-diabetic mice. Muscles were incubated for $30 \mathrm{~min}$ at $37^{\circ} \mathrm{C}$ in $1.5 \mathrm{ml} \mathrm{KRB}$ BSA, $2 \mathrm{mM}$ pyruvate, and insulin at the concentrations indicated. At the end of the 30 -min incubation period, $\left[{ }^{14} \mathrm{C}\right] 2$ deoxyglucose $(0.5 \mathrm{mM}, 0.2 \mu \mathrm{Ci} / \mathrm{vial})$ was added for $10 \mathrm{~min}$ to measure 2-deoxyglucose uptake (A and B). At the end of incubation, the washing procedure and protein determination were performed for each individual muscle as described in Methods. The percent of maximal insulin effect on 2-deoxyglucose uptake $(\mathrm{C})$ was determined by dividing the increment due to insulin at each hormone concentration (stimulated value-basal value) by the maximal increment in insulin effect at $6.7 \mathrm{nM}$. Each point $(\mathrm{A}, \mathrm{B})$ is the mean $\pm \mathrm{SEM}$ of five to eight (control), nine (48-h-fasted), or five (diabetic) muscles.

port. To test the latter possibility, the effect of insulin on glycogen synthase activation was measured in muscles incubated in the absence of glucose. Under this condition (Fig. 8A), insulin markedly activated glycogen synthase in muscles from controls, 48-h-fasted, and diabetic mice. Furthermore, as observed in glycogen synthesis (Figs. 6 and 7), submaximal doses of insulin were more effective in activating glycogen synthase in muscles from 48-h-fasted and from diabetic mice than in muscles from controls (Fig. 8A and B). Thus, a halfmaximal effective concentration was $\cong 2 \mathrm{nM}$ for controls and $0.5 \mathrm{nM}$ for 48 -h-fasted and streptozotocin-diabetic mice. Fasting and diabetes did not affect either the basal percentage of active (I) form of glycogen synthase or the extent of enzyme activation by insulin (Table IV). Total enzyme activity was slightly decreased in muscles from 48-h-fasted mice, and unaltered in muscles from diabetic animals.

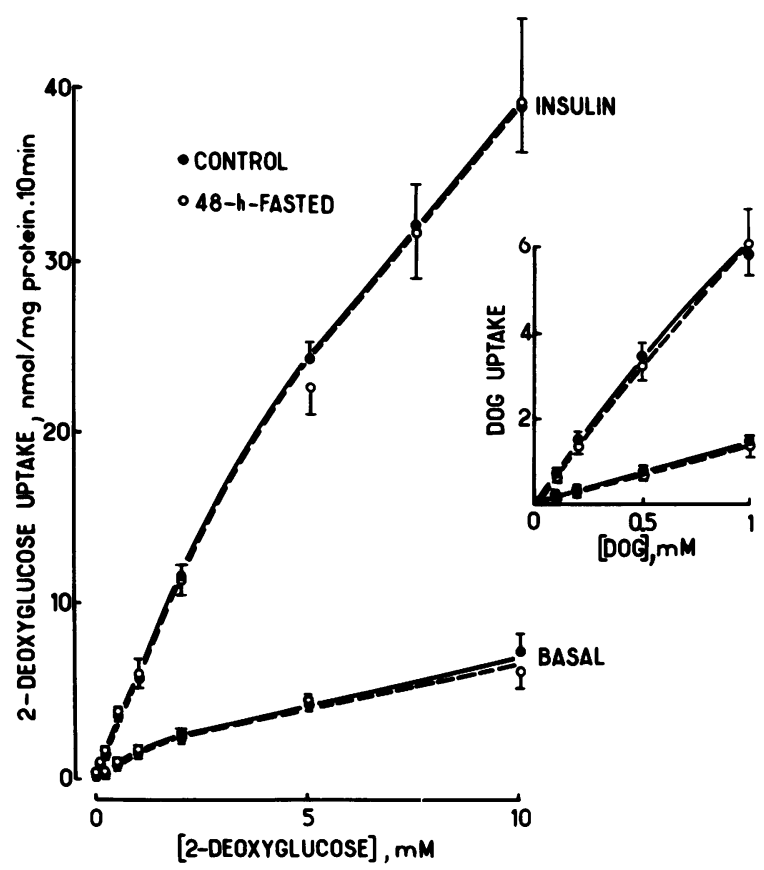

Figure 4 Deoxyglucose uptake by soleus muscles of control and 48-h-fasted mice as a function of substrate concentration. Deoxyglucose uptake was measured during a 10-min incubation following a 30-min preincubation without (basal) or with insulin (33 $\mathrm{nM}$ ), as described in Fig. 3. The inset shows 2deoxyglucose (DOG) uptake at low hexose concentration. Each value is the mean $\pm S E M$ of 6-11 muscles.

\section{DISCUSSION}

In these studies we have investigated the consequences of two insulinopenic states, fasting and streptozotocin diabetes, on insulin binding and effects on glucose

TABLE III

Effect of Phloridzin on Deoxyglucose Uptake by Soleus Muscles of Control and 48-h-fasted Mice

\begin{tabular}{lcc}
\hline & \multicolumn{2}{c}{ 2-Deoxyglucose uptake } \\
\cline { 2 - 3 } Phloridzin, $m M \ldots \ldots \ldots$ & 0 & 5 \\
\hline & \multicolumn{2}{c}{$n$ mol/mg } \\
Controtein $\cdot 10 \mathrm{~min}$ \\
Basal & $0.61 \pm 0.04$ & $0.19 \pm 0.02$ \\
Insulin & $3.44 \pm 0.33$ & $0.82 \pm 0.06$ \\
48-h-fasted & & \\
Basal & $0.54 \pm 0.05$ & $0.19 \pm 0.02$ \\
Insulin & $3.27 \pm 0.32$ & $0.75 \pm 0.04$ \\
\hline
\end{tabular}

Deoxyglucose uptake was measured during a 10-min incubation after a 30-min preincubation with or without insulin $(33 \mathrm{nM})$, and with or without phloridzin $(5 \mathrm{mM})$, as described in Fig. 3. Each value is the mean \pm SEM of five muscles. Differences between 48 -h-fasted and control mice were not significant. 


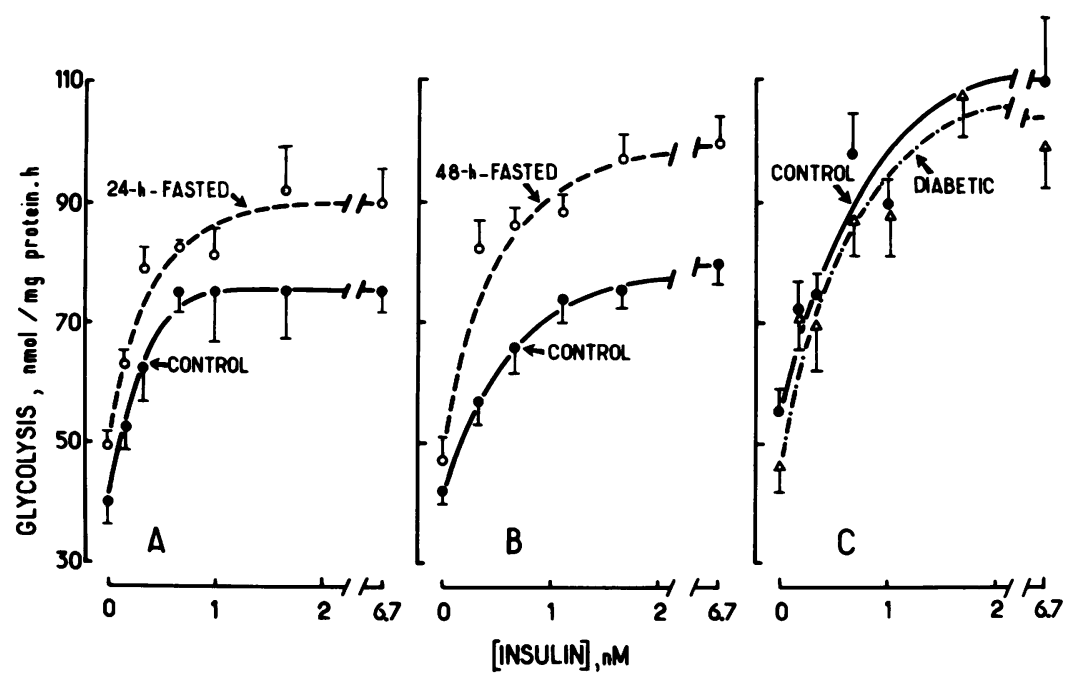

FIGURE 5 Insulin effect on glycolysis in soleus muscles of control, fasted, and streptozotocindiabetic mice. Muscles were incubated for $1 \mathrm{~h}$ at $37^{\circ} \mathrm{C}$ in $1.5 \mathrm{ml} \mathrm{KRB-BSA}, 5 \mathrm{mM}\left[5-{ }^{3} \mathrm{H}\right] \mathrm{glucose}$, and insulin at the concentrations indicated. This incubation was preceded by a 15-min preincubation in the same medium where glucose was replaced by $2 \mathrm{mM}$ pyruvate, with or without insulin. Data are expressed as nanomoles of glucose converted into $\mathrm{H}_{2} \mathrm{O}$ through a glycolytic pathway. Each value is the mean \pm SEM of 6 ( $\mathrm{A}$ and $\mathrm{C}$ ) or $12(\mathrm{~B})$ muscles.

transport and metabolism in a skeletal muscle, the mouse soleus. The results presented have shown that the binding of insulin is increased in muscles from 48-h-fasted mice and from streptozotocin-diabetic mice. It has been reported that fasting and insulinopenic diabetes in the rat are accompanied by an increase in insulin binding to isolated adipocytes (1-6). Such an increase has also been described in liver plasma membranes from streptozotocin-diabetic rats (27-29). These changes in insulin binding have been related to an increase either in receptor number $(4,6,27-29)$, or in receptor affinity $(1,2,5)$, or both (3). On the other hand, no change was detected in liver membranes from 48 -hfasted rats (27) or in circulating monocytes from 48-hfasted nonobese humans (30). Our results in the study of muscles from both streptozotocin-diabetic and 48-hfasted mice show that the increase in insulin binding occurs only at low insulin concentrations $(<3 \mathrm{nM})$,

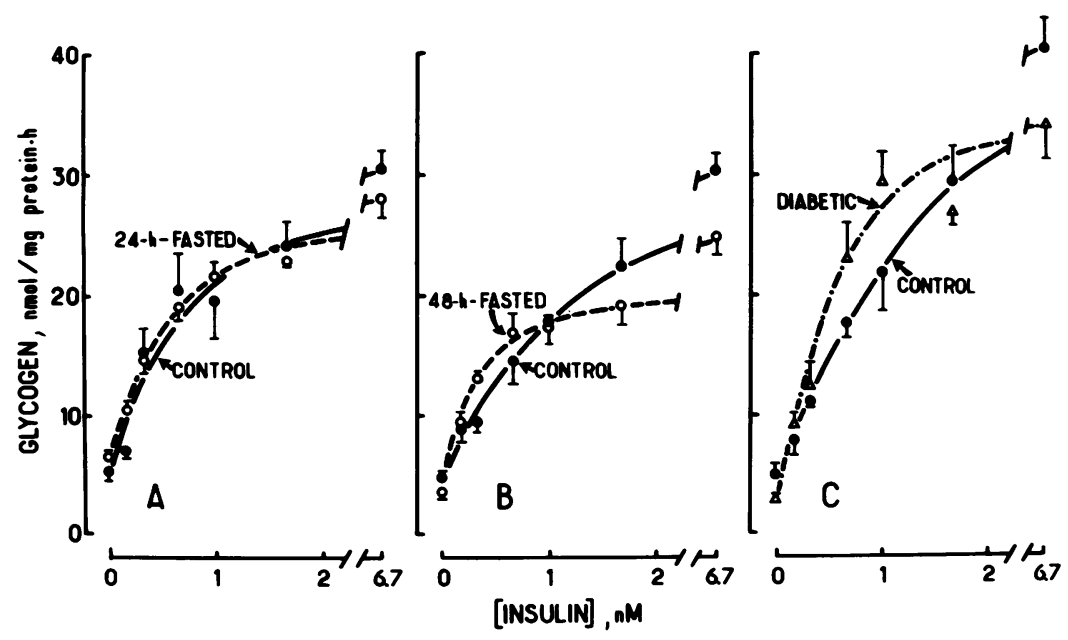

FigURE 6 Insulin effect on glycogen synthesis in soleus muscles of control, fasted, and streptozotocin-diabetic mice. Muscles were incubated as described in Fig. 5. Data are expressed as nanomoles of glucose incorporated into glycogen. Each point is the mean $\pm S E M$ of five to seven muscles. 


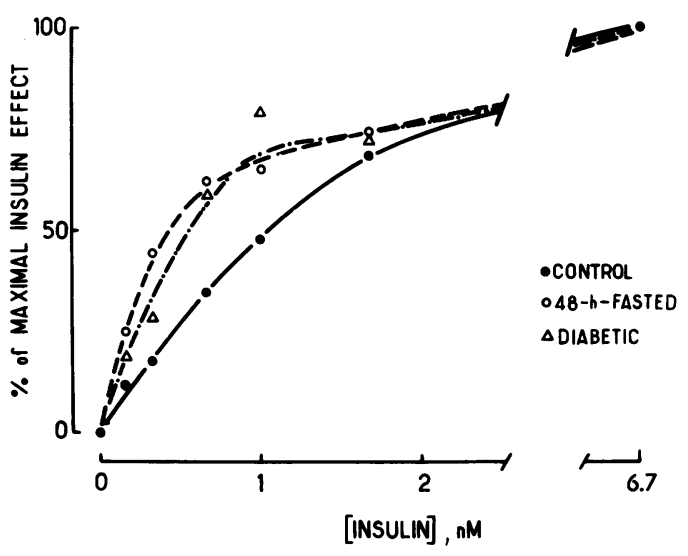

FIGURE 7 Insulin dose responses (percent of maximal effect) on glycogen synthesis in soleus muscles of control, fasted, and streptozotocin-diabetic mice. Experimental conditions were as described in Fig. 6. The percent of maximal insulin effect was obtained from data shown in Fig. 6, using the mode of calculation described in Fig. 3.

suggesting an increase in receptor affinity rather than a change in receptor number. The observed increase is in agreement with the concept of an inverse relationship between ambient insulin levels and insulin binding (30-32), although the exact mechanisms for such changes in receptor affinity and/or number are presently unknown. Although the endogenous insulin level was already markedly decreased after a 24 -h fast (Table I), no change in insulin binding could be detected in muscles at this stage, a finding at variance with the increase in binding reported in the study of adipocytes from 24-h-fasted rats (2).

Because soleus muscle has been shown to exhibit spare receptors $(13,14)$, the functional consequence of the observed increase in insulin binding should be an increased insulin response at insulin levels that will occupy fewer receptor sites than the number required for a maximal effect, with the increase in insulin binding not affecting per se the maximal response to the hormone $(2,13,32)$. Therefore, if the effector system(s) is (are) intact, the consequence of an increased insulin binding should be a leftward shift of the insulin dose-response curves. This was indeed found to be the case for 2deoxyglucose uptake (Fig. 3C), glycogen synthesis (Fig. 7), and glycogen synthase activation (Fig. 8B) in muscles from both 48-h-fasted and streptozotocindiabetic mice. A leftward shift has also been reported for the insulin-stimulated glucose transport in adipocytes from fasted and diabetic rats $(2,3)$. Such a shift was not observed in soleus muscle for glycolysis (Fig. 5); this suggests that in muscles from fasted or diabetic

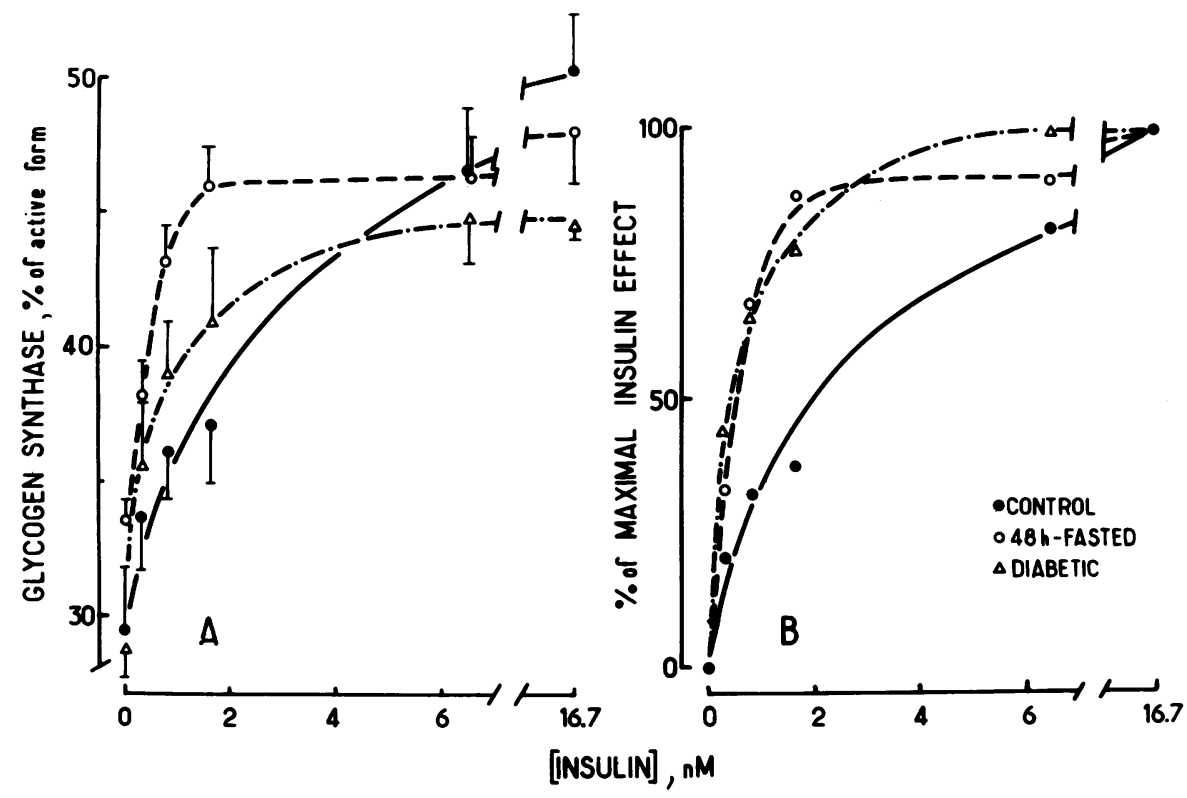

FIGURE 8 Insulin effect on glycogen synthase activation in soleus muscles of control, fasted, or streptozotocin-diabetic mice. Muscles were first incubated for $90 \mathrm{~min}$ at $37^{\circ} \mathrm{C}$ in the absence of insulin as described in Fig. 1. They were then incubated for $30 \mathrm{~min}$ at $37^{\circ} \mathrm{C}$ in the same medium containing insulin at the concentrations indicated. At the end of incubation, muscles were freezeclamped, homogenized, and glycogen synthase activity was measured as described in Methods, in the absence (I form) or in the presence (I + D form) of 7.2 mM glucose-6-phosphate. The data are expressed in panel $A$ as the percent of active form $(I / I+D \times 100)$, or in panel $B$ as the percent of maximal insulin effect obtained from data shown in $A$, using the mode of calculation described in Fig. 3. Each point is the mean \pm SEM of 9 (control), 12 (48-h-fasted), or 6 (diabetic) muscles. 
TABLE IV

Glycogen Synthase Activity in Soleus Muscles of Control, 48-h-fasted and Streptozotocin Diabetic Mice

\begin{tabular}{lcccc}
\hline & \multicolumn{3}{c}{ Percentage of active (I) form } & $\begin{array}{c}\text { Total activity } \\
(\mathrm{I}+\mathrm{D})\end{array}$ \\
\cline { 2 - 5 } & Basal & Insulin & $\Delta$ & $\begin{array}{c}\text { nmol/mg } \\
\text { protein } \cdot \text { min }\end{array}$ \\
& & & & \\
Control & $35.6 \pm 2.7$ & $48.1 \pm 3.0$ & $12.6 \pm 1.2$ & $18.5 \pm 0.5$ \\
48-h-fasted & $39.7 \pm 2.6$ & $53.8 \pm 2.9$ & $14.1 \pm 1.6$ & $14.9 \pm 0.6^{*}$ \\
Diabetic & $34.6 \pm 1.7$ & $46.2 \pm 2.7$ & $11.7 \pm 1.1$ & $17.6 \pm 0.6$ \\
\hline
\end{tabular}

Muscles were treated as described in Fig. 8. At the end of incubation, muscles were freeze-clamped, homogenized, and glycogen synthase activity was measured as described in Methods, in the absence (I form) or in the presence (I + D form) of $7.2 \mathrm{mM}$ glucose-6-phosphate. The two muscles from one mouse were studied as pairs incubated with or without (basal) insulin (33 nM). Results are means \pm SEM of 12-14 muscles. $\Delta$ is the increase in the percentage of glycogen synthase active form brought about by insulin.

* Difference between 48-h-fasted and control mice is significant with $P<0.001$.

mice some step(s) in the glycolytic pathway is (are) altered, that may counterbalance the increase in insulin binding. No difference could be observed between controls and 24-h-fasted mice for insulin binding or for insulin dose-response curves. It thus appears that the increase in insulin binding in muscles from 48 -h-fasted and from streptozotocin-diabetic mice is accompanied by a marked increase in insulin sensitivity, i.e., the biological responses of muscle to low concentrations of insulin are enhanced. This is in agreement with a recent report of an increased insulin sensitivity of the perfused hindquarter of 48-h-fasted rats (33).

Another striking feature of the present study is the observation that, at maximally effective doses, insulin elicited in muscles from 48-h-fasted and from streptozotocin-diabetic mice responses were identical to, or even greater than, the responses observed in control mice. Thus soleus muscles from insulinopenic animals have a normal overall capacity of the glucose transport system, of the glycolytic pathway, and of glycogen synthesis. This is in marked contrast to the classic assertion that glucose uptake and utilization are decreased in muscle as a result of fasting and insulinopenic diabetes (34). However, most studies have been performed in the perfused rat heart or in the isolated diaphragm which are highly specialized, constantly contracting muscles. It has previously been shown that heart and skeletal muscle differ markedly from each other in the regulation of glucose metabolism $(10,35)$. For example, the glycogen content increased in heart $(35,36)$ and decreased in soleus (Table I) or in hindquarter (11) muscles during fasting or insulinopenic diabetes. Furthermore, as observed in the present study with soleus muscles from 48-h-fasted mice, recent studies in the perfused rat hindquarter $(11,12$, 33) have shown that neither glycolysis nor the capacity for glucose transport is inhibited during starvation.

The present study has also provided some information with regard to the regulation of glycogen synthesis in skeletal muscle (Fig. 8, Table IV). The activation of glycogen synthesis by insulin results from two types of effects: $(a)$ an activation of glucose transport and/or phosphorylation, as measured by the stimulation of 2deoxyglucose uptake (Fig. 3 ), and (b) an activation of glycogen synthase. The results presented in Fig. 8 (where muscles were incubated in the absence of glucose) clearly indicate that insulin directly activates glycogen synthase, independently of its effect on glucose transport and metabolism. This type of regulation, independent of glucose, also occurs in the perfused rat heart (36). However, marked differences are again observed between heart and skeletal muscle. In our studies, insulin markedly activated glycogen synthase in soleus muscles from streptozotocin-diabetic mice, whereas in perfused heart from alloxandiabetic rats glycogen synthase was completely unresponsive to insulin (36). It can also be observed that basal glycogen synthase active form (Table IV) was similar in muscles from control and insulinopenic animals, a result that differs from the observation of a decreased basal active form of the enzyme in heart or liver from diabetic rats (36-38).

Overall insulin resistance has been demonstrated in insulinopenic states in man (39) and in animals $(40,41)$. Insulin resistance in vivo may stem from alterations at the target cell level, or changes in circulating levels of hormones and fuels, or both. The results observed in vitro with soleus muscle in the present study are different from those reported with adipocytes during fasting and streptozotocin diabetes (1-6). Thus, both basal and insulin-stimulated glucose uptake and utilization in rat adipocytes have been found to be markedly reduced in these two insulinopenic situations. In contrast to the results in adipocytes, basal and insulin-stimulated glucose uptake and metabolism were essentially unaltered in soleus muscles from fasted or diabetic mice. Furthermore, soleus muscles from insulinopenic mice exhibit an increased sensitivity to insulin (i.e., biological responses to submaximal insulin levels are enhanced), possibly the result of increased affinity of the receptor to the hormone. This was also found to be the case with adipocytes from insulinopenic animals $(2,3)$. In the latter cells, however, multiple defects in effector systems distal to the insulin receptor markedly depress insulin responsiveness (i.e., biological responses to maximally effective insulin levels) and impede the expression of increased insulin sensitivity. In contrast, the integrity of effector 
systems in soleus muscles from insulinopenic mice allows for full responsiveness of the target tissue and permits a clear-cut demonstration of increased insulin sensitivity. It has recently been hypothesized from observations in adipocytes that the level of insulin to which cells are chronically exposed may play a role in the regulation of the capacity of the glucose transport system (42). Our data do not suggest that this represents a general mechanism operating in all tissues.

In conclusion, these studies have shown that soleus muscles from 48-h-fasted or streptozotocin-diabetic mice are hypersensitive to low concentrations of insulin and normally responsive to maximally effective doses of the hormone. Despite opposed changes in blood glucose in vivo, these two states exhibit remarkably similar patterns of insulin action and glucose utilization in a skeletal muscle studied in vitro. Several points may explain the apparent discrepancy between the present results with soleus muscle in vitro and overall in vivo insulin resistance in insulinopenic states. It is possible that some other skeletal muscles behave differently from the soleus, although the marked similarity between our data and those observed in the perfused rat hindquarter (33) does not favor this possibility. On the other hand, a pattern of altered glucose metabolism has been reported in the rat soleus when incubated with acetoacetate or fatty acids $(43,44)$. Thus it is reasonable to assume that in insulinopenic states in vivo increases in substrates such as free fatty acids and ketone bodies (45) will interfere with muscle metabolism. Concomitant increases in circulating levels of hormones (46) that counteract insulin effects, such as glucagon, catecholamines, and glucocorticoids may also contribute to overall insulin resistance. Our results strongly suggest that the state of glucose intolerance and insulin resistance observed in insulinopenic states in vivo is not the consequence of an intrinsic defect of skeletal muscle with regard to insulin-stimulated glucose utilization.

\section{ACKNOWLEDGMENTS}

We are greatly indebted to Mrs. N. Grenier-Brossette for expert technical help, to Mr. G. Visciano for illustration work, and to Miss J. Duch for excellent secretarial assistance.

This study was supported by grants A.T.P. 38.76 .70 and C.R.L. 79.5.215.4 from Institut National de la Santé et de la Recherche Médicale (I.N.S.E.R.M.), by grant 75-7-1366 from Délégation Générale à la Recherche Scientifique et Technique (D.G.R.S.T., France), by the Fondation pour la Recherche Médicale, and by a grant from the University of Nice.

\section{REFERENCES}

1. Wieringa, T., and H. M. J. Krans. 1978. Reduced glucose transport and increased binding of insulin in adipocytes from diabetic and fasted rats. Biochim. Biophys. Acta. 538: $563-570$.
2. Olefsky, J. M. 1976. Effects of fasting on insulin binding, glucose transport, and glucose oxidation in isolated rat adipocytes. Relationships between insulin receptors and insulin action. J. Clin. Invest. 58: 1450-1460.

3. Kobayashi, M., and J. M. Olefsky. 1979. Effects of streptozotocin-induced diabetes on insulin binding, glucose transport, and intracellular glucose metabolism in isolated rat adipocytes. Diabetes. 28: 87-95.

4. Kasuga, M., Y. Akanuma, Y. Iwamoto, and K. Kosaka. 1978. Insulin binding and glucose metabolism in adipocytes of streptozotocin-diabetic rats. Am. J. Physiol. 235: E175E182.

5. Schoenle, E., J. Zapf, and E. R. Froesch. 1977. Effects of insulin and NSILA on adipocytes of normal and diabetic rats: receptor binding, glucose transport and glucose metabolism. Diabetologia. 13: 243-249.

6. Kasuga, M., Y. Akanuma, Y. Iwamoto, and K. Kosaka. 1977. Effects of fasting and refeeding on insulin receptors and glucose metabolism in rat adipocytes. Endocrinology. 100: $1384-1390$.

7. Randle, P. J., E. A. Newsholme, and P. B. Garland. 1964. Regulation of glucose uptake by muscle. 8. Effects of fatty acids, ketone bodies and pyruvate, and of alloxan diabetes and starvation, on the uptake and metabolic fate of glucose in rat heart and diaphragm muscles. Biochem.J. 93: 652-665.

8. Kipnis, D. M., and C. F. Cori. 1960. Studies of tissue permeability. VI. The penetration and phosphorylation of 2-deoxyglucose in the rat diaphragm of diabetic rats. J. Biol. Chem. 235: 3070-3075.

9. Neely, J. R., and H. E. Morgan. 1974. Relationship between carbohydrate and lipid metabolism and the energy balance of heart muscle. Annu. Rev. Physiol. 36: 413-459.

10. Berger, M., S. A. Hagg, M. N. Goodman, and N. B. Ruderman. 1976. Glucose metabolism in perfused skeletal muscle. Effects of starvation, diabetes, fatty acids, acetoacetate, insulin and exercise on glucose uptake and disposition. Biochem. J. 158: 191-202.

11. Goodman, M. N., M. Berger, and N. B. Ruderman. 1974. Glucose metabolism in rat skeletal muscle at rest. Effect of starvation, diabetes, ketone bodies and free fatty acids. Diabetes. 23: 881-888.

12. Berger, M., S. Hagg, and N. B. Ruderman. 1975. Glucose metabolism in perfused skeletal muscle. Interaction of insulin and exercise on glucose uptake. Biochem. J. 146: 231-238.

13. Le Marchand-Brustel, Y., B. Jeanrenaud, and P. Freychet. 1978. Insulin binding and effects in isolated soleus muscle of lean and obese mice. Am. J. Physiol. 234: E348-E358.

14. Le Marchand-Brustel, Y., and P. Freychet. 1978. Studies of insulin insensitivity in soleus muscles of obese mice. Metab. Clin. Exp. 27(Suppl. 2): 1982-1993.

15. Bergmeyer, H. U., and E. Bernt. 1970. Glucose bestimmung mit Glucose-oxydase und Peroxydase. In Methoden der enzymatischen Analyse. H. U. Bergmeyer, editor. Verlag Chemie, Weinheim, West Germany. 2nd edition. 1250-1259.

16. Cuendet, G. S., E. G. Loten, B. Jeanrenaud, and A. E. Renold. 1976. Decreased basal, noninsulin-stimulated glucose uptake and metabolism by skeletal soleus muscle isolated from obese-hyperglycemic $(o b / o b)$ mice. J. Clin. Invest. 58: 1078-1088.

17. Chen, R. F. 1967. Removal of fatty acids from serum albumin by charcoal treatment. J. Biol. Chem. 242: 173-181.

18. Ashcroft, S. J. H., L. C. C. Weerasinghe, J. M. Bassett, and 
P. J. Randle. 1972. The pentose cycle and insulin release in mouse pancreatic islets. Biochem. J. 126: 525-532.

19. Thomas, J. A., K. K. Schlender, and J. Larner. 1968. A rapid filter paper assay for UDPglucose-glycogen glucosyltransferase, including an improved biosynthesis of UDP- ${ }^{14} \mathrm{C}$-glucose. Anal. Biochem. 25: 486-499.

20. Chan, T. M., and J. H. Exton. 1976. A rapid method for the determination of glycogen content and radioactivity in small quantities of tissue or isolated hepatocytes. Anal. Biochem. 71: 96-105.

21. Herbert, V., K. S. Lau, G. W. Gottlieb, and J. J. Bleicher. 1965. Coated charcoal immunoassay of insulin. J. Clin. Endocrinol. 25: 1375-1384.

22. Lowry, O. H., N. J. Rosebrough, A. L. Farr, and R. J. Randall. 1951. Protein measurement with the Folin phenol reagent. J. Biol. Chem. 193: 265-275.

23. Snedecor, G. W., and W. G. Cochran. 1967. Statistical Methods, 6th edition, Iowa State University Press, Ames, Iowa.

24. Scatchard, G. 1949. The attractions of proteins for small molecules and ions. Ann. N. Y. Acad. Sci. 51: 660-672.

25. LeFevre, P. G. 1961. Sugar transport in the red blood cell: structure-activity relationships in substrates and antagonists. Pharmacol. Rev. 13: 39-70.

26. Larner, J., and C. Villar-Palasi. 1971. Glycogen synthase and its control. Curr. Top. Cell. Regul. 3: 195-236.

27. Davidson, M. B., and S. A. Kaplan. 1977. Increased insulin binding by hepatic plasma membranes from diabetic rats. Normalization by insulin therapy. J. Clin. Invest. 59: $22-30$.

28. Soman, V., and P. Felig. 1978. Glucagon binding and adenylate cyclase activity in liver membranes from untreated and insulin-treated diabetic rats.J. Clin. Invest. 61: $552-560$.

29. Hepp, K. D. 1977. Studies on the mechanism of insulin action: basic concepts and clinical implications. Diabetologia. 13: 177-186.

30. Bar, R. S., P. Gorden, J. Roth, C. R. Kahn, and P. De Meyts. 1976. Fluctuations in the affinity and concentration of insulin receptors on circulating monocytes of obese patients. Effects of starvation, refeeding and dieting. $J$. Clin. Invest. 58: 1123-1135.

31. DeFronzo, R. A., V. Soman, R. S. Sherwin, R. Hendler, and P. Felig. 1978. Insulin binding to monocytes and insulin action in human obesity, starvation, and refeeding. J. Clin. Invest. 62: 204-213.

32. Freychet, P. 1976. Interactions of polypeptide hormones with cell membrane receptors: studies with insulin and glucagon. Diabetologia. 12: 83-100.
33. Ruderman, N. B., M. N. Goodman, C. A. Conover, and M. Berger. 1979. Substrate utilization in perfused skeletal muscle. Diabetes. 28(Suppl. 1): 13-17.

34. Randle, P. J., P. B. Garland, C. N. Hales, E. A. Newsholme, R. M. Denton, and C. J. Pogson. 1966. Interaction of metabolism and the physiological role of insulin. Recent Prog. Horm. Res. 22: 1-44.

35. Adrouny, G. A. 1969. Differential patterns of glycogen metabolism in cardiac and skeletal muscles. Am. J. Physiol. 217: 686-693.

36. Miller, T. B., Jr. 1978. A dual role for insulin in the regulation of cardiac glycogen synthase. J. Biol. Chem. 253: 5389-5394.

37. Khandelwal, R. L., S. M. Zinman, and E. J. Zebrowski. 1977. The effect of streptozotocin-induced diabetes and of insulin supplementation on glycogen metabolism in rat liver. Biochem. J. 168: 541-548.

38. Miller, T. B., Jr. 1978. Effects of diabetes on glucose regulation of enzymes involved in hepatic glycogen metabolism. Am. J. Physiol. 234: E13-E19.

39. Martin, R. I. R., and A. E. Stocks. 1968. Insulin sensitivity and vascular disease in insulin-dependent diabetics. $\mathrm{Br}$. Med.J. 2: 81-82.

40. Reaven, G. M., W. S. Sageman, and R. S. Swenson. 1977. Development of insulin resistance in normal dogs following alloxan-induced insulin deficiency. Diabetologia. 13: 459-462.

41. Feldman, J. M., and H. E. Lebovitz. 1970. Effect of fasting on insulin secretion and action in mice. Endocrinology. 86: $313-321$.

42. Olefsky, J. M., and M. Kobayashi. 1978. Ability of circulating insulin to chronically regulate the cellular glucose transport system. Metab. Clin.Exp. 27(Suppl. 2): 1917- 1929 .

43. Cuendet, G. S., E. G. Loten, and A. E. Renold. 1975. Evidence that the glucose-fatty acid cycle is operative in isolated skeletal (soleus) muscle. Diabetologia. 12: 336 (Abstr.).

44. Maizels, E. Z., N. B. Ruderman, M. N. Goodman, and D. Lau. 1977. Effect of acetoacetate on glucose metabolism in the soleus and extensor digitorum longus muscles of the rat. Biochem. J. 162: 557-568.

45. Cahill, G. F., Jr., M. G. Herrera, A. P. Morgan, J. S. Soeldner, J. Steinke, P. L. Levy, G. A. Reichard, Jr., and D. M. Kipnis. 1966. Hormone-fuel interrelationships during fasting. J. Clin. Invest. 45: 1751-1769.

46. Williams, R. H., and D. Porte, Jr. 1974. The pancreas. In Textbook of Endocrinology. R. H. Williams, editor. W. B. Saunders Co., Philadelphia. 5th edition. 502-626. 